$$
\text { DOE } \mid E R / 6 / 196--T)
$$

The kinetics of aromatic-hydrocarbon biodegradation and concomitant gaochemical reactions pertinent to groundwater systems

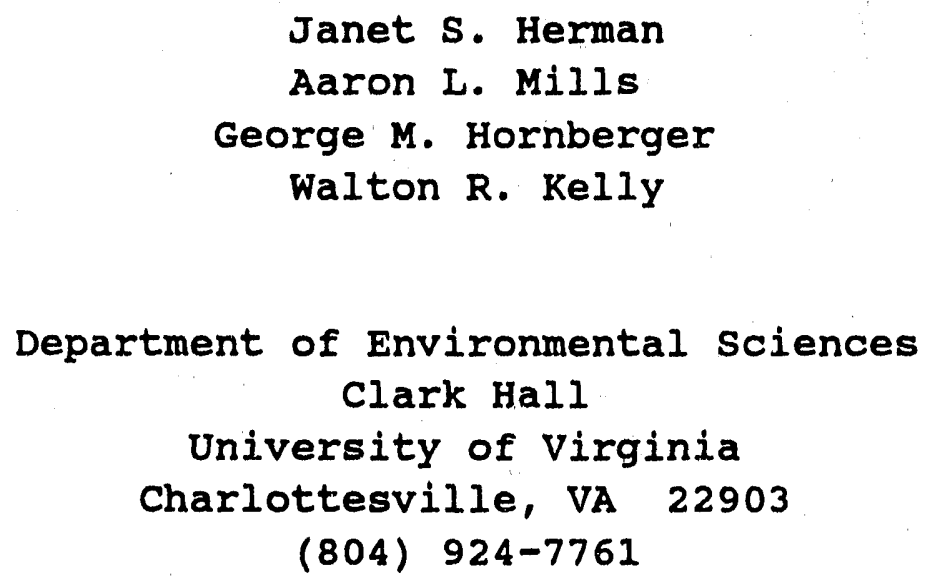

U.S. Department of Energy / OHER

Subsurface Enjironmental Research Initiative

Award number DE-FG05-91ER61196

Interim Technical Progress Report with Incremental Request Submitted at the end of the first 6-month period.

February 1, 1992 
Award number DE-FG05-91ER61196: 6-month progress report :

\section{The kinetics of aroatic-hydrocarbon biodegradation and concomitant geochomical reactions pertinent to groundwater systems}

\section{PROJECT BUREARY}

Aromatic hydrocarbons are contaminants of concern in many environmental restoration projects, both alone and as mixed wastes, and are known to undergo microbial degradation under both aerobic and anaerobic conditions. These biodegradation reactions have direct impact on the geochemistry of the subsurface environment, yet this interaction is largely unquantified. We are currently engaged in (1) a series of controlled and replicated laboratory experiments designed to examine and quantify the rates of geochemical reactions driven by aromatichydrocarbon biodegradation and (2) modification and use of a geochemical reaction-path model by including expressions for the reaction rates. In laboratory experiments, we are investigating (1) the biodegradation rates of benzene, toluene, and xylene, individually and in mixtures, and (2) the resulting changes in geochemical conditions. Results from the experiments will be interpreted in light of a rate model so that parameters of a rate law may be estimated and the rate law incorporated into a geochemical reaction-path model. Time-course predictions can then be made concerning the occurrence of the contaminant hydrocarbon and its impact on geochemical reactions in hypothetical hydrogeologic settings. We anticipate that this work will (1) greatly enhance our understanding of the rate of biodegradation reactions of aromatics and of the interaction between biodegradation and other geochemical reactions in a groundwater system and (2) improve our ability to predict the behavior of aromatic hydrocarbons and associated geochemical changes in contaminated hydrogeologic systems.

\section{DISCLAIMER}

\footnotetext{
This report was prepared as an account of work sponsored by an agency of the United States Government. Neither the United States Government nor any agency thereof, vor any of their employees, makes any warranty, express or implied, or assumes any legal liability or responsibility for the accuracy, completeness, or usefulness of any information, apparatus, product, or process disclosed, or represents that its use would not infringe privately owned rights. Reference herein to any specific commercial product, process, or service by trade name, trademark, manufacturer, or otherwise does not necessarily constitute or imply its endorsement, recommendation, or favoring by the United States Government or any agency thereof. The views and opinions of authors expressed herein do not necessarily state or reflect those of the United States Government or any agency thereof.
} 


\section{WORK ACCOKPLIBHED TO DATE}

\section{Laboratory experimentation}

Batch and column experiments using quartz sand, artificial dilute groundwater, aromatic hydrocarbon (benzene, toluene, xylene, alone and as mixtures), and bacteria have been conducted to measure rates of change in the concentrations of aromatic hydrocarbon, biomass, and a number of inorganic geochemical parameters such as dissolved inorganic carbon, oxygen, protons, and nitrate.

The experiments to date have focused primarily on aerobic, unamended systems. Some work with calcite in place of quartz was recently begun. Experimentation with iron(III) coated quartz grains is planned to begin later this spring.

Some results of the research to date are presented in the appended abstracts of presentations given at professional meetings. (Also, see listing of published abstracts.)

\section{Eata analysig}

Results of batch experiments were used to show that no mass transport limitation of the rates from the column experiments was observed.

Runs over a range of initial hydrocarbon concentration were completed in columns so that the rate data could be fitted to a kinetic model. A substrate-saturation model allowing for cell growth yields the best fit to the data.

\section{Geochemical modeling}

The rate law has been incorporated into an existing geochemical code, EQ3/6, and some preliminary runs exercising the code have been completed. A one-week visit to Lawrence Livermore National Laboratory was necessary to obtain advice from colleagues more familiar with EQ3/6.

\section{WORK TO BE DONE}

Because it is only 6 months into a three-year project, there is certainly much yet to be done. In terms of chemical variables in batch experimentation, more on anaerobic systems and on calcite and Fe(III) amended systems must be done. The results of the carbon budget to date indicate that more attention must be given to reactive intermediates in the biodegradation reactions. Most of the geochemical modelinç; lies before us to do. 
Award number DE-FG05-91ER61196: 6-month progress report

\section{PERBONREL}

The principal investigators are Janet $S$. Herman, Aaron $L$. Mills, and George M. Hornberger as originally submitted in the proposal. The Ph.D. student Walton $R$. Kelly has been involved in this research since before the beginning of the funded period; he continues to be involved. An M.S. student, Patricia $w$. Guy began research on this project during the summer of 1991 and is continuing.

\section{BUDGETARY IBBUEB}

Continuity of the research support is requested here. The second year of funding would begin August 1, 1992. The second year of funding remains as originally requested. A copy of the original budget is appended. 


\section{PUBLI BHED PRODUCTS OY THE REBEARCE}

\section{Presentations (with published abstracts) $*$}

1. W.R. Kelly, J.S. Herman, and A.I. Mills. "Aerobic benzene biodegradation and resulting chemical changes in groundwater: a laboratory column study." American Geophysical Union, Spring Meeting, Baltimore, MD, May 1990.

2. Walton R. Kelly, Janet S. Herman, and Aaron L. Mills. "Geochemical changes resulting from biodegradation of aromatic hydrocarbons: a laboratory study." Geological Society of America, Annual Meeting, Dallas, TX, November 1990.

3. W.R. Kelly, J.S. Herman, and A.L. Mills. "Geochemical changes resulting from biodegradation of aromatic hydrocarbons: a laboratory column study." American Geophysical Union, Spring Meeting, Baltimore, MD, May 1991.

4. W.R. Kelly, J.S. Herman, and A.L. Mills. "Kinetics of BTX biodegradation and resulting geochemical changes in groundwater: a laboratory study." American Geophysical Union, Fall Meeting, San Francisco, CA, December 1991.

Abstracts Accepted for Presentations (with published abstracts) $X$

1. W.R. Kelly, P.W. Guy, and J.S. Herman. "stoichiometry and rate of mineral-solution interactions in the presence of BTX biodegradation." Third International Goldschmidt Conference, Reston, VA, May 1992.

2. J.S. Herman, W.R. Kelly, P.W. Guy, and S.J. Kauffman. "Modeling rates of geochemical reactions driven by aromatic hydrocarbon biodegradation." Seventh International symposium on Water-Rock Interactions, Park City, UT, July 1992.

(abostanterenmenc) 

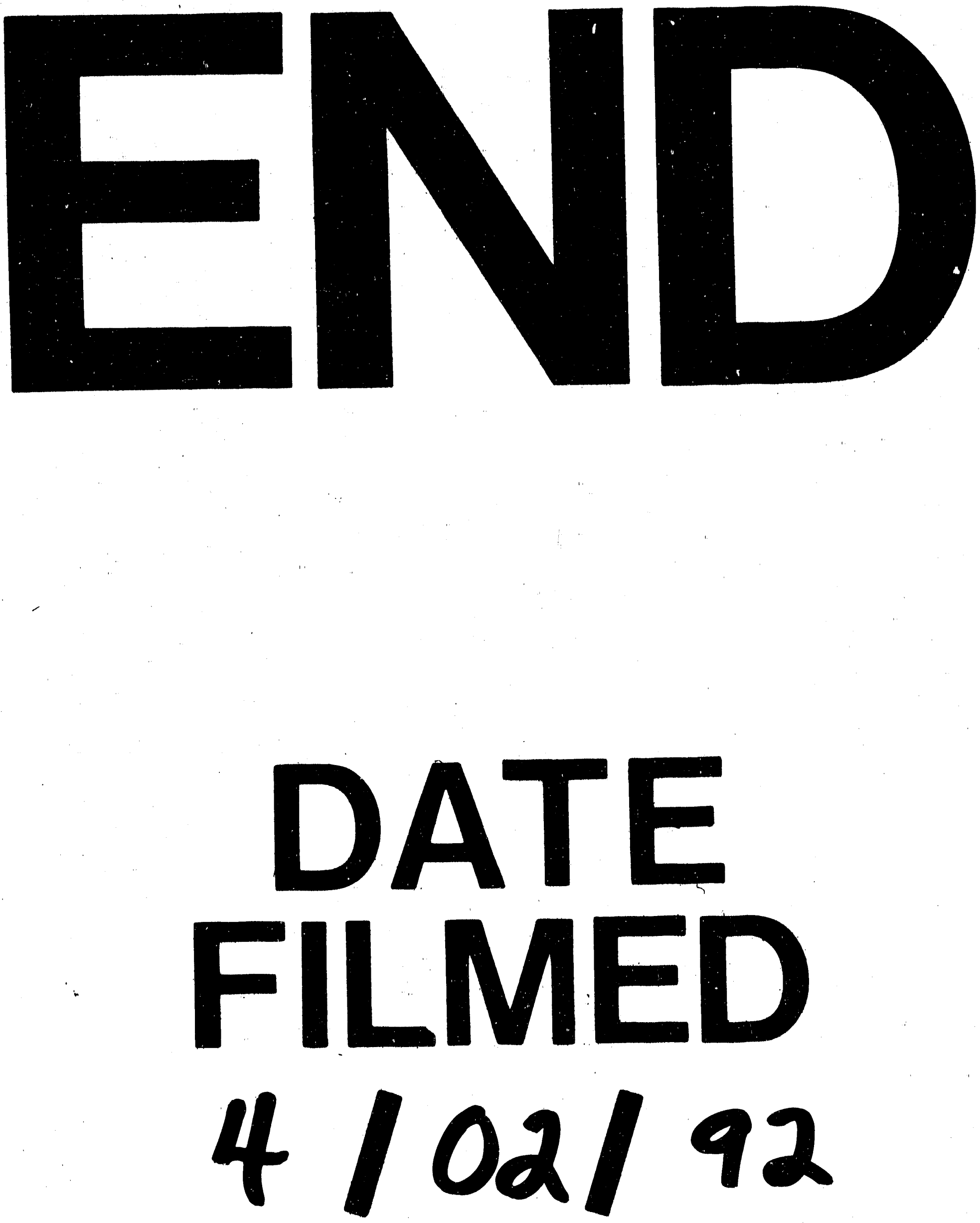
